\title{
WAYS OF INCREASING MOTIVATION OF CADETS TO LEARN A FOREIGN LANGUAGE
}

\author{
Liliya Honcharuk \\ Candidate of Philological Sciences, Head of the Department of Special Language Training, \\ Military Institute of Taras Shevchenko National University of Kyiv, Ukraine \\ e-mail: bondarenkoliliya1981@gmail.com, orcid.org/0000000239652933
}

\section{Tetiana Riabokuchma}

Assistant Professor, Military Institute of Taras Shevchenko National University of Kyiv, Ukraine e-mail: tanja91174@ukr.net, orcid.org/0000000254984784

\section{Andrzej Kryński}

Professor, Ph.D., Polonia University in Czestochowa, Interdisciplinary Faculty, Poland e-mail: a.krynski@ap.edu.pl, orcid.org/0000-0001-9635-023X

\section{Summary}

The article deals with cadets' motivation to learn a foreign language and the ways to increase it. Such types of motivation as intrinsic motivation, extrinsic motivation, integrative motivation, instrumental motivation, general language learning motivation, and classroom learning motivation are described and discussed in the research. Similarities and differences of these kinds of motivation are analysed. The importance of motivation as a driving force in the process of learning a foreign language and mastering language skills is highlighted in the paper. The role of a teacher in providing a positive environment for the formation of students' motivation is considered in the research. Special attention is paid to the necessity of ensuring motivation of cadets while learning a language of another culture. Main ways of increasing their motivation to engage into the language learning process are proposed and characterized. Professional orientation of education is also taken into account while proposing effective methods of cadets' motivation enhancement.

Keywords: motivation, cadets, professional orientation, foreign language, military sector.

\section{DOI: https://doi.org/10.23856/4017}

\section{Introduction}

In the modern world learning a foreign language has become an integral part of developing international relations and providing effective cross-cultural communication between representatives of various nations around the globe. Schools and higher educational institutions try to provide all the necessary means of teaching / learning foreign languages in order for students to stay motivated and consequently achieve success in mastering a foreign language. The role of students' motivation in education, learning a foreign language in particular, has become a major concern of teachers, lecturers, researchers and other specialists in the field of education, since it is one of the key factors that influence the desire to study a language of another community. Thus, the aim of the present research is to identify the most effective ways to increase the motivation of second language learners, cadets in particular. In order to achieve this aim, a combination of several scientific methods was used in the study. Descriptive method was applied to collect and analyse information presented in studies relevant to the topic of the research, define main characteristics of motivation. Comparative method made it possible to conduct comparison of 
different types of motivation. Research synthesis and analysis contributed to providing and discussing examples of ways to increase cadets' motivation to learn a foreign language.

\section{Concept of motivation and its main types}

A starting point for finding out the most effective ways of increasing language learners' motivation is to investigate and discuss the existent definitions of this concept and consider its main types. Generally, motivation is considered to be a psychological term. APA Dictionary of Psychology (2020) defines it as "the impetus that gives purpose or direction to behavior and operates in humans at a conscious or unconscious level". Motivation in education is considered as one of the most important factors that influences the success of language learning (Dornyei, 1998). Language learning motivation means the extent to which a person works on learning a language due to his desire to do so and the satisfaction he experiences during this process (Gardner, 2007).

Today different types and kinds of motivation are distinguished. Having analysed present classifications of motivation, several were chosen to be considered in this research as the ones that contribute to reaching the purpose of the paper. For instance, Diana Stirling describes the difference between extrinsic and intrinsic motivation. The first is characterized as the one that provides incentive to participate in a process which may not be pleasing or engaging, but which may offer some benefits for an individual. Intrinsic motivation, in turn, comes from within an individual. It inspires people to take actions even when there is no external stimulus or reward (Stirling, 2014).

Of course, these definitions encompass only the most general features of motivation and do not include deeper and more complicated ones, however, they provide a general insight into what these two types of motivation are.

R. C. Gardner and W. E. Lambert also distinguish between two types of motivation: integrative motivation and instrumental motivation (Gardner \& Lambert, 1972). Integrative motivation, similar to intrinsic motivation, means learning a foreign language for pleasure and comes from within an individual. Instrumental motivation, like extrinsic one, implies language learning for achieving immediate and practical aims, and in this case a person expects to obtain some benefit or reward (Tsai \& Chang, 2013).

So, which of these kinds of motivation drives students to learn a language? Which one is more significant in achieving success in foreign language learning? Obviously, all of them are of great importance. Any language learning process cannot be effective without engaging both classes of motivation (intrinsic / integrative and extrinsic / instrumental). On the one hand, intrinsic / integrative motivation drives students to learn a language because of their inner desire to discover the world, get familiar with other cultures, traditions, improve their existing skills, be able to communicate with native speakers freely and thus widen their outlook. On the other hand, extrinsic / instrumental motivation combined with the intrinsic / integrative type inspires language learners to acquire knowledge in order to receive high grades, teacher's praise, find a well-paid job in the future and be financially independent. As a result, these are two essential parts of one process that cannot exist without one another.

In his research into motivation and second language acquisition, R. C. Gardner also distinguishes between two types of motivation: general language learning motivation and classroom learning motivation. The author defines language learning motivation as a general type of motivation that exists in any foreign language learning context, it is inherent in every individual, who learns a language of another culture. The researcher describes it as a relatively stable class of motivation, but it may be changed in accordance with certain conditions. Classroom learning motivation is considered as an integral part of motivation and refers specifically to motivation 
in the classroom situation or any other situation that provides for learning a language. Consequently, this type of motivation is influenced by various factors associated with a foreign language class, such as person's perception of a certain task, a teacher, class atmosphere, learning materials, etc. The author also emphasizes that this type of motivation is inevitably influenced by general language learning motivation, and adds that both classes of motivation cannot be distinguished in a very real sense, but at the same time they both are operative (Gardner, 2007). Hence, a correspondence between the proposed classes of motivation and the ones mentioned above can be traced. General language learning motivation refers to intrinsic / integrative motivation as it clearly comes from within an individual. Classroom learning motivation, being influenced by various external factors, may be associated with extrinsic / instrumental motivation.

\section{Importance of motivation in teaching a foreign language to cadets}

Today almost all spheres of human activity require knowledge of at least one foreign language. One of the issues that cause lack of motivation to learn a foreign language is underestimation of its importance in a modern life. A lot of experienced foreign language teachers note that it is almost impossible to teach a person who does not have motivation. Only those who desire to learn a language, who are, first of all, intrinsically motivated, can successfully master a foreign language. It is motivation that guarantees effective engagement into the whole learning process. Of course, intrinsic motivation requires the support of the extrinsic one. However, the latter does not last long if the source of influence is not permanent and convincing enough. Therefore, it is necessary to start the process of forming both intrinsic and extrinsic types of motivation to learn a foreign language as early as possible. According to H. Voloshyna, these are foreign language teachers who should lay the foundation for further motivational process (Voloshyna, 2014).

The need for effective mastery of a foreign language is especially growing within cadets in connection with the expansion of professional tasks assigned to them. Accordingly, it necessitates an increase in the level of motivation of cadets in the educational process.

Motivation of cadets to learn a foreign language should encompass the level of attention and effort of a cadet related to the performance of tasks at a practical class. The level of educational activity of cadets depends on the level of their intrinsic motivational processes during the educational process. In other words, the motives for learning are the driving force in the process of professional growth. The dominance of intrinsic motivation is characterized by the emergence of cadets' own initiative during classes. If extrinsic motives prevail in the process of learning a foreign language, the personality does not develop fully. Thus, intrinsic motives should dominate in order for cadets to master a foreign language successfully (Honcharuk et al., 2020).

It should also be noted that high-achieving students and low-performing students usually differ not in the level of intelligence, but in strength, quality and type of motivation they have to educational activities. A high level of motivation may compensate for the lack of knowledge, skills and abilities. Instead, no matter how capable and intelligent students are, the lack of the desire and aspiration to learn a language will not let them achieve success in mastering a foreign language (Bets, 2015).

\section{Methods to increase cadets' motivation}

As it is known, teaching a foreign language requires the creation of artificial motivation. In this case, a teacher should create a positive motivational atmosphere and make learners interested in classroom activities (Honcharuk et al., 2020). 
V. H. Ryndak and A. V. Moskvyna point out that it is necessary for a teacher to make a wide range of objective values of the world become the subject of awareness and experience of an individual, to make objective values become subjectively significant, stable life landmarks and value orientations of a person. In order to do this, a teacher needs to acquaint language learners with the concepts that contradict their imagination, discuss them, encourage students to formulate their ideas, think of alternative explanations. It is also important to do this in a free and relaxed way in order to eliminate fear of making a mistake (Ryndak \& Moskvyna, 2001: 125).

It is worth noting that professional orientation and professional motives also play a key role in the development of language learning motivation. Consequently, it is important to pay attention to the professional orientation of education to increase motivation for educational activities. This can be done by emphasizing the importance of learning a language for further professional activities and through the introduction of situations that simulate future professional activity into the educational process (Bets, 2015).

In order to emphasize the importance of learning a foreign language for cadets for their future professional activities, and consequently increase their motivation, it is necessary to organize meetings and hold conferences (lectures, debates, conversations) with people, who have achieved success in the military sector and who can prove that knowledge of a language has helped them reach success in their career (Honcharuk et al., 2020). Such meetings relieve the monotony of cadets' classroom routine and help them start thinking more critically, analyse the current situation of their language proficiency and find ways how to improve it.

Organizing foreign language speaking clubs can also contribute to the increase of cadets' motivation. But here, it is necessary to take into account the fact that such clubs should be interest-oriented, rather than professionally oriented. In other words, while visiting such clubs, cadets should have an opportunity to study a language in its vast variety, not limited only to their professional vocabulary.

In addition, it is essential for a teacher to use modern communication techniques that will promote effective mastering of a foreign language and increase the level of motivation. These are the use of interactive forms, methods and techniques of teaching, including role-playing games in accordance with professional activities; the use of modern technologies in the field of digitalization of education, such as virtual educational environment (Honcharuk et al., 2020).

Motivation to learn a foreign language also requires future specialists in the military sector to be aware of their current values and how they are connected to future professional activities (Podoliak \& Yurchenko, 2008: 159). They should be aware of the requirements that are put forward by their future profession (including foreign language skills); cadets should know how to act in non-standard situations, which can be role-played during foreign language classes. It is also necessary to form a positive self-image, adequate professional self-esteem of a cadet as a researcher; develop the need and ability to work independently with foreign literature; provide necessary conditions for self-education; stimulate the desire of a cadet to self-improvement (Bets, 2015).

Another important thing in motivating cadets to learn a foreign language is encourage them to self-study. Self-study promotes the development of creative thinking, independent decision-making, setting and successfully achieving new goals, taking responsibility for educational tasks, ability to carry out critical and effective self-analysis.

\section{Conclusions}

The study suggests that motivation is an inherent component in education and it greatly influences learners' success and the level of achievements in mastering a foreign language. 
Motivation is a complicated notion that is made up of many constituents that are closely related. All types of motivation studied in the research are beneficial in a foreign language learning process.

The role of a teacher in increasing students' motivation is highly important, since this is the duty of a teacher to make students interested in learning activities and create a positive classroom atmosphere. While teaching a foreign language to cadets, professional motives need to be taken into account. Cadets should be aware of the importance of foreign language learning for their future professional activities. Holding meetings, lectures with successful specialists in the military sector, organizing speaking clubs, using modern technologies in the educational process, encouraging self-study are effective and extremely important methods for increasing cadets' motivation to learn a foreign language.

\section{References}

APA Dictionary of Psychology. (2020). [Electronic resource]. Retrieved from https:// dictionary.apa.org/motivation. [in English].

Bets, I. O. (2015). Rozvytok motyvatsii yak odna z pedahohichnykh umov formuvannia naukovo-doslidnytskoi kompetentnosti maibutnikh ofitseriv-prykordonnykiv [Development of motivation as one of the pedagogical conditions of formation of research competence of future border officers]. Visnyk Natsionalnoi akademii derzhavnoi prykordonnoi sluzhby Ukrainy, 4. [Electronic resource]. Retrieved from http://nbuv.gov.ua/UJRN/Vnadped_2015_4_4. [in Ukrainian]. Dornyei, Z. (1998). Motivation in second and foreign language learning. Language Teaching, 31, 117-135. DOI: https://doi.org/10.1017/S026144480001315X. [in English].

Gardner, R. C. (2007). Motivation and second language acquisition. Porta Linguarum, 8, 9-20. [in English].

Gardner, R. C., Lambert, W. E. (1972). Attitudes and motivation in second language learning. Rowley: Newbury House. [in English].

Honcharuk, L, Riabokuchma, T., Khmel, O. (2020). Motyvatsiia kursantiv do vyvchennia inozemnoi movy yak osnova yakisnoi profesiinoi pidhotovky [Motivation of cadets to studying foreign language as the basis of high quality professional training]. Sciences of Europe, 48(4), 41-43. [in Ukrainian].

Podoliak, L. H., Yurchenko, V. I. (2008). Psykholohiia Vyshchoi Shkoly [Psychology of higher education]. Kyiv: Karavela. [in Ukrainian].

Ryndak, V. H., Moskvyna, A. V. (2001). Lichnost. Tvorchestvo. Razvitie [Personality. Creativity. Development]. Moscow: Pedagogicheskiy vestnik. [in Russian].

Stirling, D. (2014). Motivation in education. Learning Development Institute. [Electronic resource]. Retrieved from https://www.researchgate.net/profile/Diana_Stirling/publication/ 266141351_Motivation_in_Education/links/5426d4540cf26120b7b344e8/Motivation-in-Education.pdf. [in English].

Tsai, C. C., Chang, I. C. (2013). The study on motivation and anxiety of English learning of students at a Taiwan Technical University. International Journal of English Language Teaching. 1(1), 24-41. [in English].

Voloshyna, H. H. (2014). Shliakhy pidvyshchennia motyvatsii u navchanni inozemnym movam studentiv nemovnykh vyshchykh navchalnykh zakladiv [Ways to increase motivation in teaching foreign languages to students of non-language higher education institutions]. Naukovyi visnyk Natsionalnoho universytetu bioresursiv i pryrodokorystuvannia Ukrainy, 199(1), 74-78. [in Ukrainian]. 